\title{
Income Distribution in Colombia
}

\section{Albert Berry and Miguel Urrutia}

This book describes the distribution of income in Colombia in the 1960's as well as trends during the previous three decades. The authors trace changes over time, present data on such factors as regional and sectoral disparities, sources of income, and the size of the industrial and agricultural establishment, and consider hypotheses that might explain the changes.

A Publication of the Economic Growth Center, Yale University $\$ 15.00$

\section{The Growth and Structure of the Chilean Economy}

From Independence to Allende

Markos J. Mamalakis

Markos Mamalakis offers a framework for expanding orthodox economic theory in order to understand the growth of developing countries and applies it to Chile.

A Publication of the Economic Growth Center, Yale University $\$ 20.00$

\section{Women in the American Economy}

\section{A Documentary History, 1675 to 1929}

W. Elliot Brownlee and Mary M. Brownlee

A carefully chosen selection of source readings exploring the diverse patterns of women's participation in the economy before the impact of the Great Depression and World War II. c. $\$ 17.50$ p. $\$ 4.95$

\section{(a) Yale University Press}

\section{Industry and Economic Decline in Seventeenth-Century Venice}

Richard Tilden Rapp

Mr. Rapp explains the paradox of seventeenth-century Venice - a republic that experienced a relative economic decline in commerce and industry with no absolute decline in overall income. The discussion focuses on common economic factors: labor supply and quality, technology and capital employment, foreign demand, and government policy. New analytical insights are offered on population, guilds, technology, and economic policy in early modern Europe.

Harvard Historical Monographs, $69 . \$ 16.50$

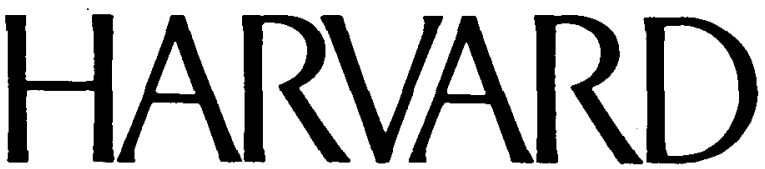

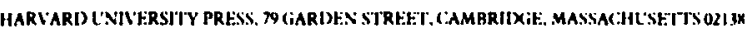




\title{
Enterprise and Entrepreneurs in Nineteenth-and Twentieth-Century France
}

\author{
edited by Edward C. Carter II, Robert Forster, \\ and Joseph N. Moody
}

The French entrepreneur has been much maligned for his concern with artistic quality at the expense of marketability. Four leading historians debate this issue. They determine the effects of the technical schools on business leadership, the importance of cultural factors and environmental conditions, and the relationship between the entrepreneur and the artist.

$\$ 12.50$

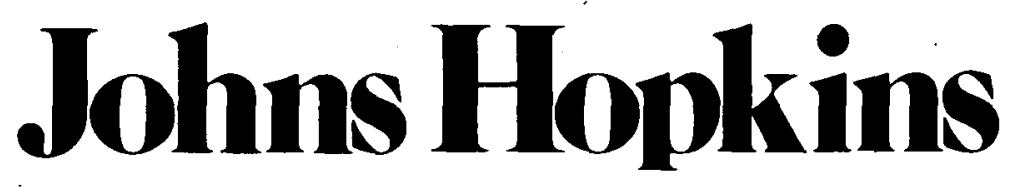

The Johns Hopkins University Press, Baltimore, Maryland 21218

\section{PASOLD PUBLICATIONS}

\section{The West Riding Wool Textile Industry$$
\text { I } 770-1835
$$ \\ A study of fixed capital formation \\ by D. T. JENKINS

$$
\mathrm{xvi}+33^{6} \mathrm{pp} \quad \$ 21.5^{\circ}
$$

\section{The West Riding Wool Textile Industry}

A catalogue of business records from the sixteenth to twentieth centuries

by Patricia Hudson $\mathrm{xviii}+5^{60} \mathrm{pp}$ $\$ 30$

The Pasold Research Fund Limited Becketts House, Edington, Near Westbury, Wilts.

Publishers of Textile History, the only textile history journal in the English language, and of other textile books including $A$ Practical Treatise on Dying by William Partridge, originally published in 1823 in U.S.A. This edition edited by K. G. Ponting. xiii +264 pp. Cloth bound $\$ 5.50$ 


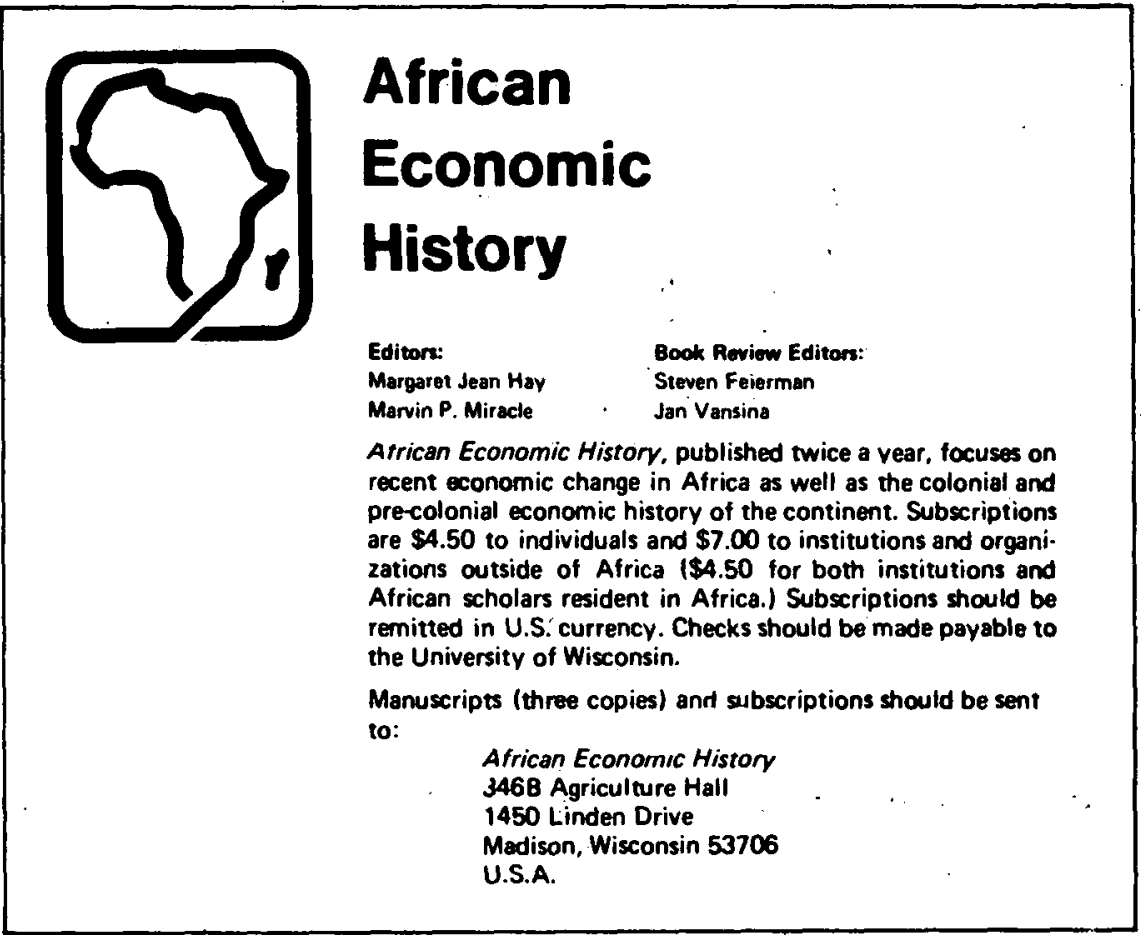

\section{E.H.A. WILL BUY}

The Economic History Association will pay $\$ 2.00$ per copy for the following issues of the Journal of Economic History:

Volume XXXIII (1973) Nos. 1 \& 2; Volume XXXIV (1974), No. 1; and Volume XXXV (1975), No. 1

$$
\text { AND }
$$

\section{SELL}

Arthur H. Cole, The Birth of a New Social Science Discipline, E.H.A., New York, 1974, 66 PP., $\$ 3.00$.

Send back issues and/or orders to Economic History Association, Eleutherian Mills Historical Library, Wilmington, Del. 19807 


\section{Rio Claro}

\section{A Brazilian Plantation System, 1820-1920}

Warren Dean. This study of the county of Rio Claro, one of the main centers of Brazilian coffee production for over a century, focuses on the successive waves of people who made up the plantation's labor force, from African-born slaves to free laborers and immigrants. In the process, it illuminates the basic character of plantation systems - their profitability, efficiency, labor relations, and local and national influence. \$rx.50

\section{Stanford University Press}

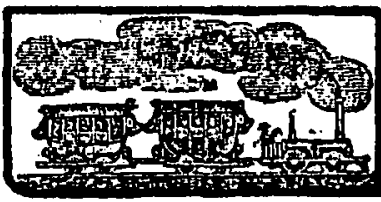

\section{? MOVING ?}

Please send changes of address for the Journal of Economic History well in advance of publication dates. To receive the March issue inform the Business Office about the change by February 15; the June issue, by May 15; the September issue, by August 15; and the December issue, by November 15.

Due to increases in postal rates it has become necessary to levy a $\$ 1.50$ postal fee on members who did not send a change in address form in time to be included in the regular second class mailing and who wish to receive the issue which has been ransomed from the U.S. Postal Service. Members will be sent notice of issues thus returned to the Business Office.

Send changes of address to Secretary, E.H.A., Eleutherian Mills Historical Library, Wilmington, Delaware 19807.

? MOVING ?

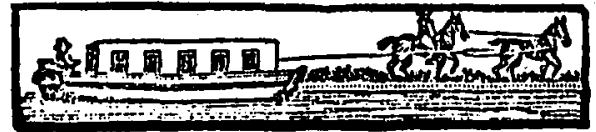




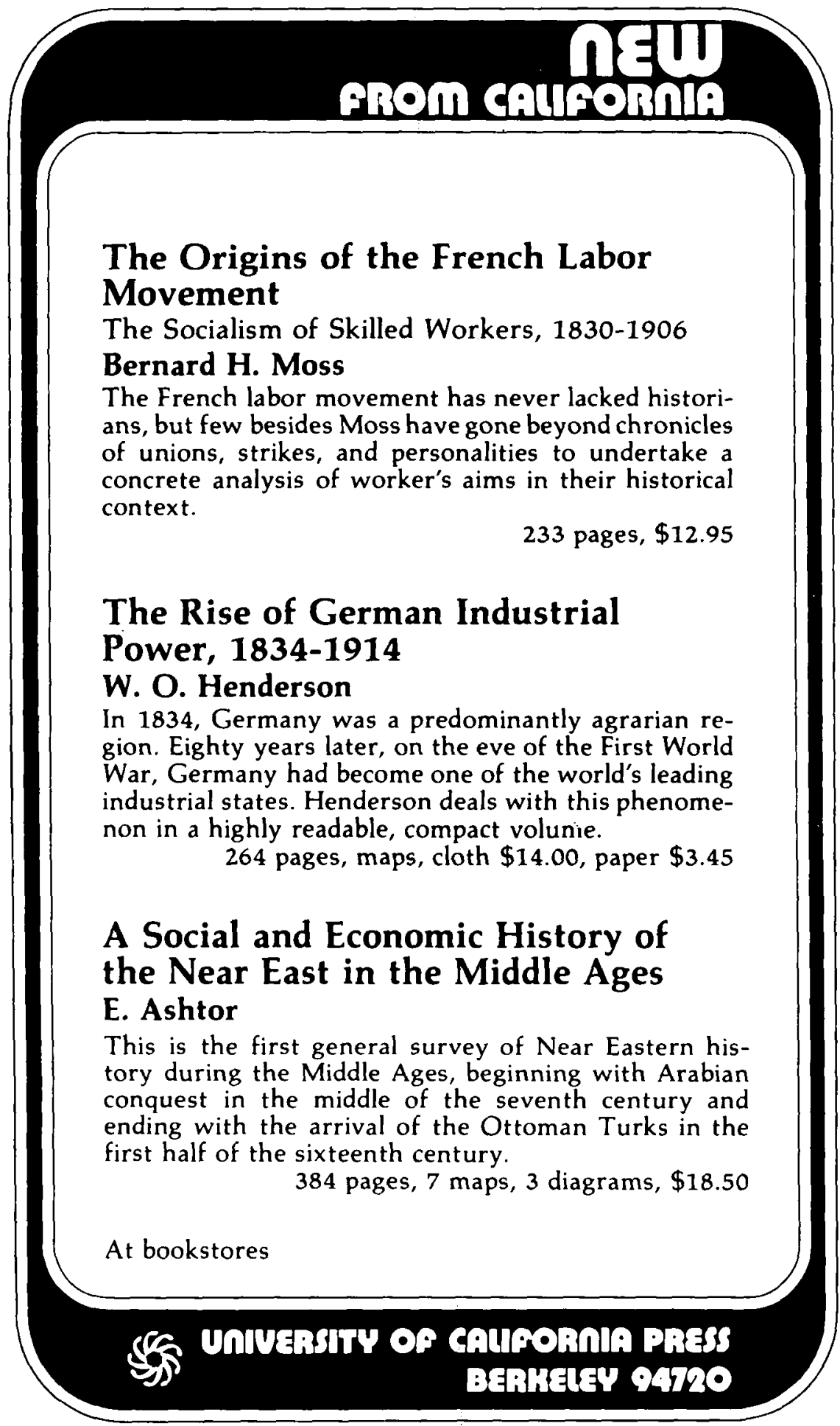




\section{THE \\ ECONOMIC HISTORY ASSOCIATION}

The Economic History Association was organized in 1940. Its purpose is to encourage research and teaching in the history of economic activity and of economic thought. It seeks to cooperate with societies devoted to the study of agricultural, business, industrial, and labor history. It aims to bring together economists, historians, statisticians, geographers, and others who find that the story of economic change throws light on their field of interest or is enriched by their contribution. Membership is open to all who are interested in the history of economic life in all its phases in the United States and other countries.

The Jounnal, of Economic History is published by The Economic History Association at The Johns Hopkins University. Books for review and correspondence concerning contributions to the Jounnal should be addressed to the editorial office: The Editors, Journal of Economic History, Milton S. Eisenhower Library, The Johns Hopkins University, Baltimore, Maryland 21218. Applications for membership should be addressed to: Richmond D. Williams, Treasurer, Eleutherian Mills Historical Library, Wilmington, Delaware 19807. 